\title{
PENGELOLAAN KEUANGAN BERBASIS APLIKASI SISTEM KEUANGAN DESA
}

\author{
Rita Martini1 $^{*}$, Resy Agustin ${ }^{1}$, Amira Fairuzdita ${ }^{1}$, Anggun Noval Murinda1 \\ ${ }^{1}$ Jurusan Akuntansi, Politeknik Negeri Sriwijaya, Palembang, Indonesia \\ *Penulis Korespondensi: ritamartini@polsri.ac.id
}

\begin{abstract}
Abstrak
Pengalokasian dana membutuhkan pengelolaan keuangan desa yang bersih, tertib, efektif, dan efisien. Sebagai pertanggungjawabannya, desa menyusun laporan keuangan yang dipermudah dengan adanya Aplikasi Sistem Keuangan Desa (SISKEUDES). Dalam penerapannya, perangkat desa mengalami kesulitan dalam pengoperasianya. Kajian ini bertujuan mengetahui penerapan aplikasi SISKEUDES dalam pengelolaan keuangan termasuk kendala-kendala yang terjadi sebenarnya di lapangan. Metode pelaksanaan dilakukan dengan pendampingan dan observasi kemudian dipaparkan secara kualitatif. Hasilnya penerapan aplikasi SISKEUDES mendukung penyediaan laporan keuangan berbasis komputer, namun dalam pelaksanaaannya terkendala oleh kompetensi sumber daya manusia dan fasilitas desa yang kurang memadai.
\end{abstract}

Kata kunci: Pengelolaan keuangan, aplikasi SISKEUDES.

\begin{abstract}
The allocation of village funds requires village finance management that is compassionate, subordinate, effective and efficient. As a responsibility, the village prepares financial reports that are facilitated by the application of the village financial system (SISKEUDES). In it's implementation, village officials have difficulties in the operation of this application. The purpose of this article is to find out the application of SISKEUDES in financial management including the actual obstacles that occur in the field. The implementation method is carried out with assistance and observations are then presented qualitatively. The result of the application implementation is supports the provision of computer-based financial reports, but in the implementation there some obstacles come from inadequate competence of human resources and village facilities.
\end{abstract}

Keywords: Financial management, SISKEUDES application.

\section{PENDAHULUAN}

Pada sistem pemerintahan yang ada dan berlaku saat ini, desa mempunyai peran yang strategis dan penting dalam membantu pemerintah daerah dalam proses penyelenggaraan pemerintahan, termasuk pembangunan. Berdasarkan Undang-Undang Republik Indonesia nomor 6 tahun 2014 tentang Desa, desa memiliki kewenangan sebagai daerah otonom. Kewenangan tersebut disertai dengan dana yang akan diberikan kepada desa berupa Dana Desa dari Pemerintah Pusat dan Alokasi Dana Desa (ADD) dari tingkat provinsi/kabupaten/kota (Republik Indonesia, 2014). Agar penggunaan dana desa menjadi efektif dan efisien, maka diperlukan pengelolaan keuangan yang baik. Pengelolaan keuangan yang baik salah satunya harus mengacu pada asas-asas pengelolaan keuangan itu sendiri (Martini dkk., 2018). Asas-asas pengelolaan keuangan desa tertuang dalam Peraturan Menteri Dalam Negeri (Permendagri) nomor 113 tahun 2014, yaitu transparan, akuntabel, partisipatif serta dilakukan dengan tertib dan disiplin anggaran (Republik Indonesia, 2014).
Beberapa disiplin anggaran yang perlu diperhatikan dalam pengelolaan keuangan desa (Republik Indonesia, 2014) yaitu: 1) Pendapatan yang direncanakan merupakan perkiraan yang terukur secara rasional yang dapat dicapai untuk setiap sumber pendapatan, sedangkan belanja yang dianggarkan merupakan batas tertinggi pengeluaran belanja; 2) Pengeluaran harus didukung dengan adanya kepastian tersedianya penerimaan dalam jumlah yang cukup dan tidak dibenarkan melaksanakan kegiatan yang belum tersedia atau tidak mencukupi kredit anggarannya dalam Anggaran Pendapatan dan Belanja Desa (APBDes)/Perubahan APBDes; 3) Semua penerimaan dan pengeluaran daerah dalam tahun anggaran yang bersangkutan harus dimasukan dalam APBDes dan dilakukan melalui Rekening Kas Desa (BPKP). Peraturan Pemerintah nomor 43 tahun 2014 pasal 93, menyatakan pengelolaan keuangan desa terdiri dari perencanaan, pelaksanaan, penatausahaan, pelaporan, dan pertanggungjawaban (Republik Indonesia, 2014). Setiap tahapan kegiatan pengelolaan keuangan desa harus dilaporkan oleh pemerintah desa sebagai bentuk pertanggungjawaban atas penggunaan dana desa. Untuk 
itu, harus ada aplikasi yang memadai untuk memudahkan proses pengelolaan keuangan desa. Sistem Keuangan Desa (SISKUEDES) merupakan aplikasi keuangan yang dikembangkan oleh Badan Pengawasan Keuangan dan Pembangunan (BPKP) berkerjasama dengan Kementerian Dalam Negeri (Mendagri) dan Kementerian Desa Pembangunan Daerah Tertinggal dan Transmigrasi (PDTT) untuk digunakan oleh pemerintah desa diseluruh Indonesia dalam pengelolaan keuangan desa secara terintegrasi, meliputi penganggaran, penatausahaan, akuntansi, dan pelaporannya. Tujuan SISKUEDES ini adalah untuk mewujudkan tata kelola keuangan desa yang bersih, tertib, efektif dan efisien. Selain itu, proses pengawasan dan pemeriksaan pertanggungjawaban keuangan desa juga lebih mudah diterapkan.

Penggunaan SISKEUDES merupakan suatu bentuk perkembangan dari Sistem Informasi Akuntasi (SIA). SIA adalah suatu kesatuan aktivitas, data, dokumen, dan teknologi yang keterkaitannya dirancang untuk mengumpulkan dan memproses data, sampai dengan menyajikan informasi kepada para pengambil keputusan di internal organisasi dan eksternal organisasi (Novita, 2016). SIA bertujuan untuk menghasilkan informasi yang cepat, tepat, dan akurat juga berguna dalam menjaga kekayaan daerah melalui pelaksanaan prosedur yang diawasi. SISKEUDES diharapkan dapat mendukung tercapainya tujuan SIA tersebut.

SISKEUDES memberikan dampak pada para pegawai, yaitu memberikan motivasi untuk bekerja dengan baik dan benar, kegiatan operasional yang lebih terata secara administratif, mengurangi adanya kecurangan, meningkatkan kinerja pegawai, dan dapat menciptakan laporan keuangan yang akuntabel (Sulina dkk., 2017). Penerapan aplikasi SISKEUDES sangat membawa perubahan yang baik, mempermudah dalam proses pelaporan pertanggungjawaban dan memberikan hasil peningkatan kualitas desa yang baik, menghasilkan pelaporan keuangan yang sesuai dengan waktu yang ditentukan, dan mengahasilkan laporan keuangan yang akuntabel (Juardi dkk., 2018). Besarnya peranan aplikasi SISKEUDES dalam pengelolaan keuangan membuat semakin pentingnya aplikasi ini untuk diterapkan di desa-desa.

Desa Talang Balai Lama yang terletak di Kabupaten Ogan Ilir telah menerapkan SISKEUDES di tahun 2017. Prangkat desa sebelumnya telah mendapatkan pelatihan khusus dari Badan Pengawasan Keuangan dan Pembangunan (BPKP) mengenai penggunaan SISKEUDES. Namun dalam penerapan di lapangan perangkat desa tersebut masih kesulitan untuk menggunakan aplikasi SISKEUDES. Hal ini terlihat dari penggunaan aplikasi SISKEUDES yang belum mandiri, perangkat desa masih melibatkan operator di desa lain atau operator di kecamatan untuk membantu mengolah data di SISKEUDES. Dalam penerapan di lapangan perangkat desa Desa Talang Balai Lama masih kesulitan untuk menggunakan aplikasi SISKEUDES. Perangkat desa masih melibatkan operator di desa lain atau operator di kecamatan untuk membantu mengolah data. Permasalahan pada pengabdian ini yaitu: 1) Bagaimana penerapan SISKEUDES dari aspek pengoperasian untuk pengelolaan keuangan di Desa Talang Balai Lama?, dan 2) Bagaimana kendala penerapan SISKEUDES di Desa Talang Balai Lama?

Program ini bertujuan melaksanakan pelatihan dan pendampingan untuk penerapan aplikasi SISKEUDES dalam pengelolaan keuangan desa. Secara khusus bertujuan:

1. Melatih dan pendampingan pengoperasian dalam penerapan aplikasi SISKEUDES terutama penginputan data penganggaran dan penatausahaan. Tahap penganggaran dan penatausahaan merupakan bagian sangat penting dalam pengelolaan keuangan desa. Pada tahap ini penggunaan keuangan desa akan terlihat peruntukannya apakah sesuai dengan yang telah dianggarkan.

2. Untuk pendampingan dalam menghadapi kendala yang terjadi di lapangan dalam proses penerapan aplikasi SISKEUDES di Desa Talang Balai Lama. Penerapan aplikasi ini terlaksana sejak tahun 2016 sehingga perlu dilihat sudah efektif untuk membantu perangkat desa dalam pengelolaan keuangan desa.

\section{BAHAN DAN METODE}

Sebelum melaksanakan kegiatan, penulis telah diberikan pelatihan oleh BPKP tentang pengoperasian SISKEUDES. Pembekalan materi oleh operator di kecamatan sekaligus penginstalan SISKEUDES untuk wilayah Kabupaten Ogan Ilir. Pengabdian ini dilakukan dengan metode pendampingan dan observasi (Gambar 1). Metode pendampingan dilakukan dengan pendekatan pembelajaran (Martini dkk., 2018), dalam hal ini untuk membantu perangkat desa dalam pengoperasian SISKEUDES.

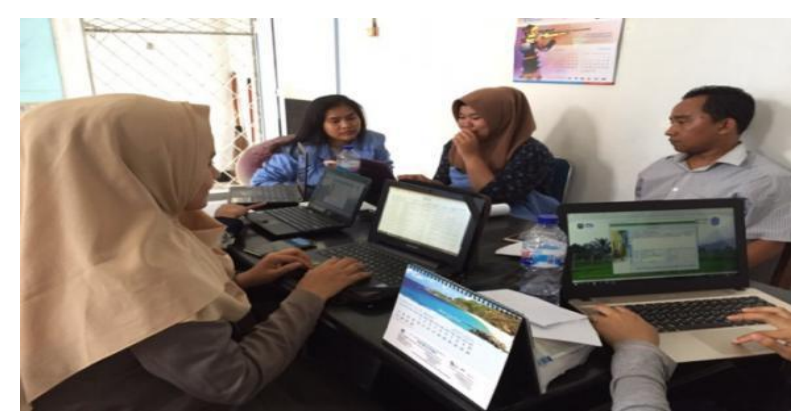

Gambar 1. Pelaksanaan Kegiatan Pengabdian

Dilakukan juga observasi terhadap pengguna aplikasi SISKEUDES, yaitu perangkat desa dan pihak-pihak terkait lainnya atas penginputan data ke aplikasi tersebut. Dari seluruh data anggaran yang diinput, lebih difokuskan kepada data anggaran yang menggunakan Dana Desa dan Alokasi Dana Desa terutama di bidang pembangunan desa. Hal ini dikarenakan bidang pembangunan desa menyerap dana yang paling besar dibandingkan bidang lainnya. Observasi juga dilakukan atas keadaan/situasi di desa tersebut yang mendukung penerapan aplikasi SISKEUDES. 
Secara lebih rinci metode pelaksanaan kegiatan disajikan pada Gambar 2.

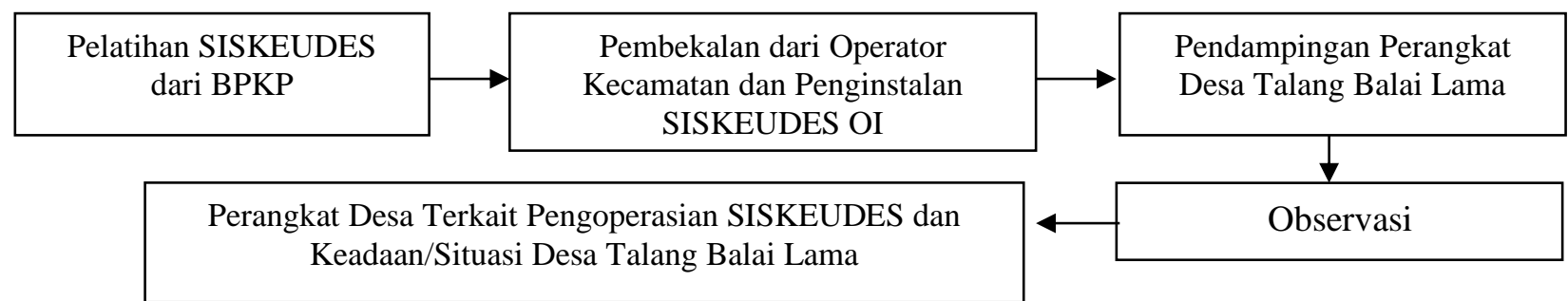

Sumber: Data diolah (2019)

Gambar 2. Metode Pelaksanaan Pengabdian

\section{HASIL DAN PEMBAHASAN}

Sumber keuangan desa yang harus diperhatikan pengelolaannya adalah keuangan desa yang bersumber dari Anggaran Pendapatan dan Belanja Negara (APBN) dan alokasi dari pemerintah daerah kabupaten/kota. Jumlah keseluruhan pengalokasian dana dari APBN atau lebih dikenal dengan Dana Desa (DD) yang diberikan oleh pemerintah pusat kepada Desa Talang Balai Lama sebesar Rp 788.001.000. Dana tersebut diberikan melalui dua tahap dimana Tahap I sebesar Rp 472.800.600 dan Tahap II sebesar Rp 315.200.400. Sedangkan dana lokasi dari pemerintah daerah kabupaten/kota atau disebut Alokasi Dana Desa (ADD) berjumlah Rp 267.694.000 yang diberikan secara dua tahap, Tahap I sebesar Rp 160.616.400 dan Tahap II sebesar Rp 107.077.600. Secara keseluruhan total pengalokasian dana ke Desa Talang Balai Lama berjumlah Rp 1.055.695.000.

\subsection{Pengelolaan Keuangan Desa dengan SISKEUDES}

Pengoperasian SISKEUDES di Desa Talang Balai Lama telah sesuai dengan prosedur dari BPKP yaitu dimulai dari penganggaran, penatausahaan dan pelaporan. Secara singkat pengelolaan keuangan dengan SISKEUDES di Desa Talang Balai Lama tersaji pada Gambar 3.

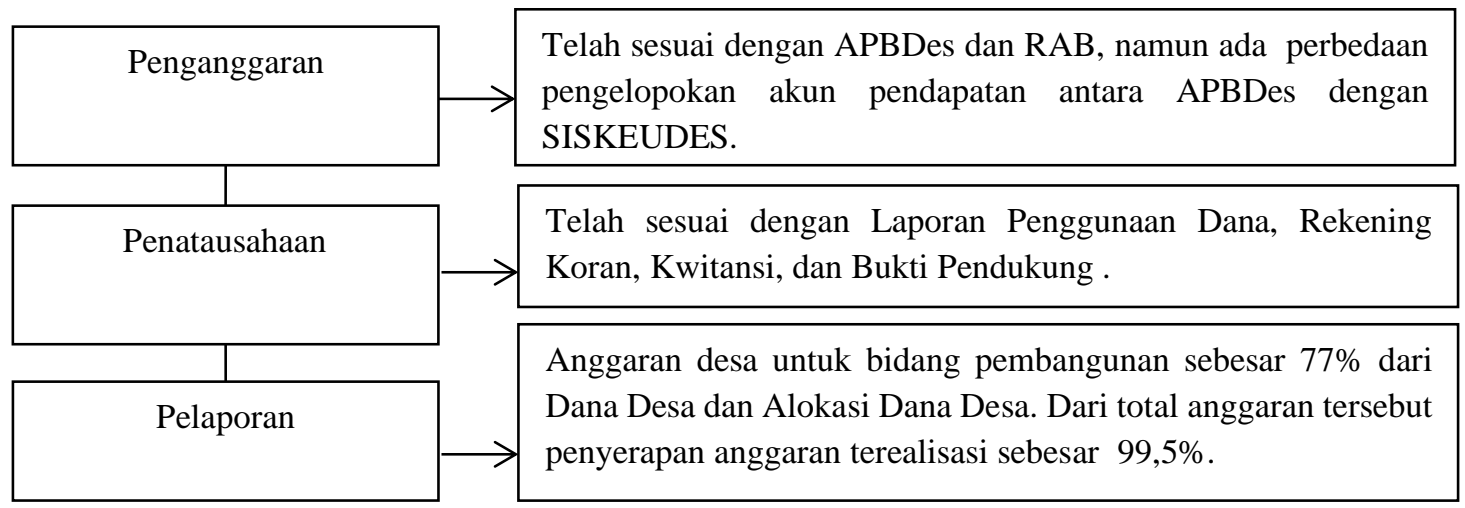

Sumber: Data diolah (2018)

Gambar 3. Tahap Pengelolaan Keuangan Desa

Pengelolaan keuangan desa dimulai dari penyusunan APBDes dan RAB (Rencana Anggaran Biaya) yang terdiri dari RAB Dana Desa Dan RAB Alokasi Dana Desa. Data APBDes dan RAB inilah yang menjadi dasar penginputan penganggaran pada aplikasi SISKEUDES.
Contoh data anggaran pendapatan desa yang diinput ke dalam SISKEUDES (Gambar 4).

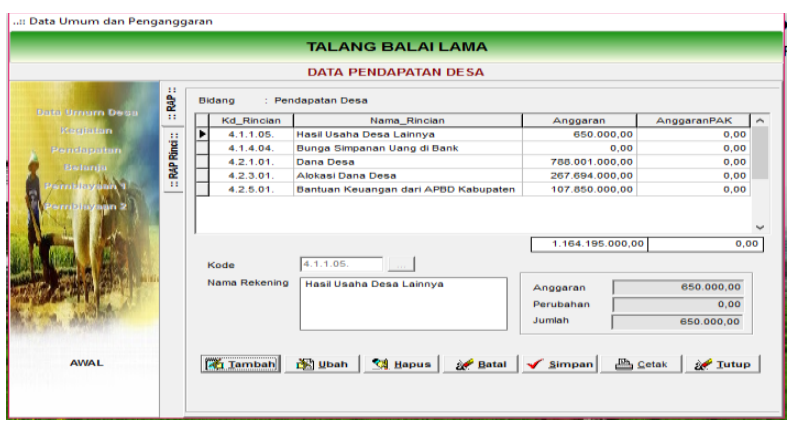

Sumber: Data diolah (2019)

Gambar 4. Anggaran Pendapatan Desa 
Jumlah anggaran pendapatan pada SISKEUDES sudah sesuai dengan APBDes, namun ada perbedaan pengelompokan akun pendapatan dimana pada APBDes akun Alokasi Dana Desa digabung menjadi Alokasi Dana Desa \& Penghasilan Tetap, sedangkan di SISKEUDES akun Alokasi Dana Desa adalah satu akun dan Penghasilan Tetap dimasukkan dalam akun Bantuan Keuangan APBD Kabupaten. Kemudian, untuk anggaran belanja dan pembiayaan sudah sesuai dengan APBDes dan RAB Desa.

Selanjutnya, kepala desa dan perangkatnya menyusun Laporan Penggunaan Dana sebagai pertanggungjawaban atas penggunaan dana desa. Penggunaan dana juga harus diinput dalam aplikasi SISKEUDES sebagai hasil dari penatausahaan keuangan desa. Data penatausahaan yang diinput dalam SISKEUDES sudah sesuai dengan Laporan Penggunaan Dana, Rekening Koran, juga bukti pendukung seperti kwitansi.

Contoh output pengoperasian penganggaran dalam aplikasi SISKEUDES di bidang pembangunan desa (Tabel 1).

Tabel 1. Anggaran Bidang Pembangunan Dari Dana Desa

\begin{tabular}{|c|c|c|}
\hline \multicolumn{3}{|c|}{$\begin{array}{c}\text { ANGGARAN PENDAPATAN DAN BELANJA DESA } \\
\text { TALANG BALAI LAMA } \\
\text { TAHUN ANGGARAN } 2017\end{array}$} \\
\hline \multicolumn{3}{|c|}{ Sumberdana : DDS Dana Desa (Dropping APBN) } \\
\hline KODE REK & URAIAN & ANGGARAN \\
\hline & & ( $\mathbf{R p})$ \\
\hline 1 & 2 & 3 \\
\hline 1 & PENDAPATAN & \\
\hline 1.2 & Pendapatan Transfer & 788.001.000,00 \\
\hline 1.2 .1 & Dana Desa & $788.001 .000,00$ \\
\hline \multirow[t]{2}{*}{1.2 .3} & Alokasi Dana Desa & $267.694 .000,00$ \\
\hline & JUMLAH PENDAPATAN & 1.055.695.000,00 \\
\hline 2 & BELANJA & \\
\hline 2.2 & Bidang Pelaksanaan Pembangunan Desa & 814.954.250,00 \\
\hline 2.2.2 & Kegiatan Pembangunan Jalan Desa & 756.654.500,00 \\
\hline 2.2.2.3 & Belanja Modal & 756.654.500,00 \\
\hline 2.2.2.3.27 & Belanja Modal Pengadaan Jalan Desa & $756.654 .500,00$ \\
\hline 2.2.19 & Kegiatan Pembangunan MCK/WC & $58.299 .750,00$ \\
\hline 2.2.19.3 & Belanja Modal & $58.299 .750,00$ \\
\hline 2.2.19.3.38 & Belanja Modal Pengadaan MCK/WC & $58.299 .750,00$ \\
\hline
\end{tabular}

Sumber: Sistem Keuangan Desa (diolah, 2019)

Anggaran di bidang pembangunan desa menyerap dana sebanyak $77 \%$ dari dana desa dan alokasi dana desa untuk kegiatan pembangunan jalan desa dan pembangunan MCK/WC (Tabel 1). Salah satu output tahap penatausahaan yang menggambarkan realisasi atas anggaran (Tabel 2).

Tabel 2. Register Kwitansi Pembayaran TALANG BALAI LAMA

REGISTER KWITANSI PEMBAYARAN TAHUN ANGGARAN 2017

\begin{tabular}{|c|c|c|l|r|}
\hline \multicolumn{4}{|c|}{} & \multicolumn{1}{c|}{ Periode 01/01/2017 s.d 31/12/2017 } \\
\hline No & Tanggal & Nomor Bukti & \multicolumn{1}{|c|}{ Uraian Pembayaran } & \multicolumn{1}{c|}{ Jumlah } \\
\hline 1 & 2 & 3 & \multicolumn{1}{c|}{4} & 5 \\
\hline 1 & $16 / 05 / 2017$ & $00007 / K W T / 03.10 / 2017$ & Pembelian Bahan dan Alat untuk MCK & $41.179 .750,00$ \\
\hline 2 & $16 / 05 / 2017$ & $00009 / K W T / 03.10 / 2017$ & Pembelian Prasasti dan Papan Proyek & $1.672 .500,00$ \\
\hline 3 & $16 / 05 / 2017$ & $00010 / K W T / 03.10 / 2017$ & $\begin{array}{l}\text { Pembayaran ke Pihak Ketiga Pengaspalan } \\
\text { Jalan Desa }\end{array}$ & $249.159 .850,00$ \\
\hline 4 & $18 / 05 / 2017$ & $00008 / K W T / 03.10 / 2017$ & $\begin{array}{l}\text { Pembayaran ke Pihak Ketiga Pengaspalan } \\
\text { Jalan Desa }\end{array}$ & $104.320 .250,00$ \\
\hline 5 & $22 / 05 / 2017$ & $00013 / K W T / 03.10 / 2017$ & Upah Tenaga Kerja Pembuatan MCK & $17.120 .000,00$ \\
\hline 6 & $14 / 08 / 2017$ & $00070 / K W T / 03.10 / 2017$ & Pembelian Alat dan Bahan Jalan & $31.744 .325,00$ \\
\hline 7 & $25 / 08 / 2017$ & $00071 / K W T / 03.10 / 2017$ & Pembelian Prasasti & $557.500,00$ \\
\hline
\end{tabular}




\begin{tabular}{|c|c|c|c|c|}
\hline \multicolumn{5}{|c|}{$\begin{array}{c}\text { TALANG BALAI LAMA } \\
\text { REGISTER KWITANSI PEMBAYARAN } \\
\text { TAHUN ANGGARAN } 2017\end{array}$} \\
\hline \multicolumn{5}{|c|}{ Periode $01 / 01 / 2017$ s.d $31 / 12 / 2017$} \\
\hline No & Tanggal & Nomor Bukti & Uraian Pembayaran & Jumlah \\
\hline 1 & 2 & 3 & 4 & 5 \\
\hline 8 & $25 / 08 / 2017$ & 00072/KWT/03.10/2017 & Upah Tenaga Kerja & $20.040 .000,00$ \\
\hline 9 & $25 / 08 / 2017$ & $00073 / \mathrm{KWT} / 03.10 / 2017$ & Pembelian Alat dan Bahan Jalan & $1.154 .575,00$ \\
\hline 10 & $28 / 11 / 2017$ & 00074/KWT/03.10/2017 & Kegiatan Pengaspalan Jalan Desa & $240.927 .802,00$ \\
\hline 11 & $29 / 12 / 2017$ & 00079/KWT/03.10/2017 & Pembelian Alat dan Bahan Jalan & $49.961 .325,00$ \\
\hline 12 & $29 / 12 / 2017$ & $00080 / \mathrm{KWT} / 03.10 / 2017$ & Pembelian Air Kerja Jalan & $220.000,00$ \\
\hline 13 & $29 / 12 / 2017$ & $00081 / \mathrm{KWT} / 03.10 / 2017$ & Pembelian Prasasti dan Papan Proyek & $1.393 .750,00$ \\
\hline 14 & $29 / 12 / 2017$ & 00082/KWT/03.10/2017 & Pembelian Alat dan Bahan Jalan & $28.962 .525,00$ \\
\hline 15 & 29/12/2017 & 00083/KWT/03.10/2017 & Pembelian Air Kerja Jalan & $20.000,00$ \\
\hline 16 & $29 / 12 / 2017$ & 00084/KWT/03.10/2017 & Pembayaran Upah Pembangunan Jalan & $19.120 .000,00$ \\
\hline 17 & $29 / 12 / 2017$ & 00085/KWT/03.10/2017 & Pembayaran Upah Pembangunan Jalan & $7.400 .000,00$ \\
\hline \multicolumn{4}{|c|}{ TOTAL } & $814.954 .152,00$ \\
\hline
\end{tabular}

Sumber: Sistem Keuangan Desa (Diolah, 2019)

Dana desa dan ADD yang terealisasi sebesar Rp 58.299.750 untuk kegiatan pembangunan MCK/WC dan Rp 756.654.402 untuk kegiatan pembangunan jalan desa. Jika dilihat secara keseluruhan, anggaran yang telah terealisasi di bidang pembangunan sebesar 99,5\% dari total anggaran dana desa dan alokasi dana desa, masing-masing sebesar $100 \%$ untuk pembangunan MCK/WC dan 99\% untuk kegiatan pembangunan jalan desa. Ini menunjukkan anggaran dana desa dan ADD khususnya di bidang pembangunan sudah terserap sangat baik, yang artinya program dan kegiatan pembangunan telah terlaksana di Desa Talang Balai Lama.

\subsection{Kendala Penerapan SISKEUDES}

Penerapan SISKEUDES memberikan dampak yang positif. SISKEUDES mendukung penyediaan informasi data yang cepat, tepat, dan akurat karena setiap data anggaran yang diinput akan disimpan dalam aplikasi dan bisa dilihat kapan saja dibutuhkan sehingga dapat menghasilkan pelaporan keuangan yang sesuai dengan waktu yang ditentukan (Juardi dkk., 2018), data akurat karena seluruh perhitungan dilakukan otomatis oleh aplikasi. SISKEUDES mendukung tujuan SIA yaitu menghasilkan informasi yang cepat, tepat, dan akurat juga berguna dalam menjaga kekayaan daerah melalui pelaksanaan prosedur yang diawasi (Novita, 2016) dan dan (Martini dkk., 2018).

Kelebihan penggunaan SISKEUDES yang terlihat dari tahap penganggaran adalah tersedianya daftar akun- akun standar penganggaran untuk pendapatan, belanja, dan pembiayaan. Perangkat desa yang bertugas dalam penginputan anggaran desa bisa langsung memilih jenis akun yang dibutuhkan lalu menginput nominal anggaran. Hal ini akan mempercepat pekerjaan perangkat desa. SISKEUDES juga mampu melakukan pengelompokan jenis sumber dana pendapatan yaitu ADD, Dana Desa (DDs), dan Bantuan Keuangan (PBK), sehingga pada saat menginput data anggaran pendapatan tinggal menyesuaikan jenis pendapatan terhadap sumber dana dari pendapatan tersebut.

Kelebihan aplikasi SISKEUDES yang terlihat di tahap penatausahaan salah satunya akses yang bertujuan untuk pengawasan dan keamanan. SISKEUDES dapat mengurangi adanya kecurangan (Sulina dkk., 2017). Tahap penatausahaan desa baru bisa dilakukan setelah dilakukan posting oleh administrator di tingkat kecamatan yang disertai dengan penguncian anggaran, sehingga menghindari adanya perubahan anggaran yang dilakukan oleh perangkat desa saat penatausahaan.

Namun, dalam penerapan SISKEUDES seringkali terhambat yang diakibatkan oleh beberapa hal yang digambarkan pada Gambar 5. 


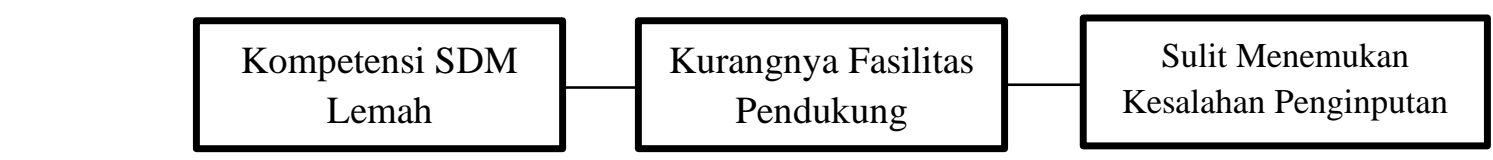

Sumber: Data diolah (2019)

Gambar 5. Kendala Penerapan SISKEUDES

Selama pelaksanaan kegiatan mulai dari pendampingan dan observasi, ditemukan penerapan aplikasi SISKEUDES belum optimal. Faktor sumber daya manusia menjadi yang paling berperan dalam hal ini. Perangkat desa yang berperan dalam pengoperasian SISKEUDES kurang memahami aplikasi tersebut. Perangkat desa tersebut seringkali lupa tahap-tahap penginputan data. Pengoperasian aplikasi ini masih dianggap rumit oleh perangkat desa. Selain itu, perangkat desa tersebut juga kurang memiliki pengetahuan tentang anggaran desa, ini terlihat dari kebingungan perangkat desa bersangkutan ketika melakukan penginputan APBDes dalam aplikasi SISKEUDES. Misalnya dalam menentukan jenis-jenis pendapatan desa apakah masuk pendapatan asli desa, pendapatan transfer, atau pendapatan lain-lain yang sah. Secara keseluruhan pengelolaan keuangan desa dengan SISKEUDES di Desa Talang Balai Lama masih tergantung pada bantuan dari operator di Kecamatan. Perangkat desa sebaiknya meningkatkan pengetahuannya baik dengan melanjutkan pendidikan maupun rutin mengikuti pelatihan terkait akuntansi desa, dana desa maupun keterampilan khusus lainnya (Martini dkk., 2019).

Penerapan SISKEUDES juga terhambat dan tidak optimal, karena tidak ada fasilitas yang memadai seperti kantor desa dan komputer. Penerapan SISKEUDES dilakukan menggunakan Laptop milik perangkat desa. Dari segi aplikasi, kendala yang sering terjadi adalah ketika terdapat kesalahan penginputan, maka sulit untuk mendeteksi kesalahan tersebut, dengan kata lain pengguna harus meneliti kembali satu persatu data yang telah diinput.

\section{KESIMPULAN}

Penerapan aplikasi SISKEUDES dalam pengoperasiannya telah sesuai prosedur dari BPKP, namun belum optimal. Faktor utama yang menghambat penerapan SISKEUDES adalah lemahnya sumber daya manusia dan terbatasnya fasilitas yang memadai. Pelatihan berkelanjutan terhadap perangkat desa sangat diperlukan untuk meningkatkan kemampuan dan daya ingatnya terkait pengoperasian aplikasi SISKEUDES. Sebaiknya juga menghadirkan tenaga kerja (dari kota) yang kompeten di bidang akuntansi pemerintahan untuk menyusun laporan keuangan berbasis aplikasi SISKEUDES sehingga tujuan penerapan aplikasi SISKEUDES tersebut bisa tercapai. Kemudian, perlu dianggarkan dana untuk pengadaan komputer sebagai fasilitas desa, terlebih lagi pembangunan kantor desa. Hal ini bertujuan agar pelaksanaan pemerintahan desa dalam pengelolaan keuangan bisa berjalan secara efektif dan efisien.

\section{DAFTAR PUSTAKA}

Juardi, M. S., Muchlis, M., \& Putri, R. A. (2018). Evaluasi Pengguanaan Aplikasi SISKEUDES dalam Upaya Peningkatan Kualitas Akuntabilitas Keuangan Desa (Studi pada Desa Jenetallasa Kec. Pallangga Kab. Gowa). Jurnal Ilmiah Akuntansi Peradaban.

Martini, R., Zulkifli, Z., Hartati, S., \& Armaini, R. (2018). Pembukuan dan Pelaporan Informasi Akuntansi Keuangan Berbasis PSAK 45: pada Panti Asuhan Al-Amanah, Palembang. Aptekmas, 1 (2), 20-29.

Martini, R., Hartati, S., Zulkifli, Z., \& Widyastuti, E. (2019). Sistem Pengendalian Intern Pemerintah atas Akuntabilitas Pengelolaan Keuangan Dana Desa di Kecamatan Sembawa. Jurnal Akdemi Akuntansi, doi:https://doi.org/10.22219/jaa.v2i1.8364

Novita, E. (2016). Analisa Implementasi Sistem Informasi Akuntansi dengan Menggunakan Brach Delivery System pada PT. Bank Rakyat Indoneis (Persero) Tbk. Kantor Cabang Mojokerto. Laporan Tugas Akhir.

Sulina, G. A., Wahyuni, M. A., \& Kurniawan, P. S. (2017). Peranan Sistem Keuangan Desa (SISKEUDES) terhadap Kinerja Pemerintah Desa ( Studi Kasus di Desa Kaba-kaba, Kecamatan Kediri, Kabupaten Tabanan). $e$ Journal S1 Ak Universitas Pendidikan Ganesha.

Republik Indonesia, Undang-Undang No. 6 Tahun 2014 tentang Desa.

Republik Indonesia, Peraturan Menteri Dalam Negeri No. 113 Tahun 2014 tentang Pengelolaan Keuangan Desa.

Republik Indonesia, Peraturan Pemerintah No. 43 tahun 2014 tentang Pengelolaan Keuangan Desa. 